\title{
T Cell Receptor $\alpha$-Chain Gene Rearrangements in B-Precursor Leukemia Are in Contrast to The Findings in T Cell Acute Lymphoblastic Leukemia Comparative Study of T Cell Receptor Gene Rearrangement in Childhood Leukemia
}

\author{
Junichi Hara, Stephen H. Benedict, Tak W. Mak, “ and Erwin W. Gelfand \\ Division of Immunology and Rheumatology, Research Institute, The Hospital for Sick Children, Toronto, Ontario M5G $1 X 8 ;$ and \\ ${ }^{*}$ Department of Medical Biophysics and Department of Immunology, Ontario Cancer Institute, Toronto, Ontario M4X 1 K9 Canada
}

\begin{abstract}
We have analyzed $T$ cell receptor $\alpha$-chain gene configuration using three genomic joining $(J)$ region probes in 64 children with acute lymphoblastic leukemia (ALL). 11 out of $18 \mathrm{~T}$ ALLs were T3 positive; $\alpha$-chain gene rearrangements were demonstrated in only two of 18 , indicating that the majority of T-ALLs would have rearrangements involving $J \alpha$ segments located upstream of these probes. In contrast, 15 out of 46 B-precursor ALLs showed rearrangements of the $\alpha$-chain gene and $\mathrm{J} \alpha$ segments located $\sim 20-30 \mathrm{~kb}$ upstream of the constant region were involved in 13 of these patients. Nine of $15 \mathrm{~B}$-precursor ALLs with rearranged $\alpha$-chain genes had rearrangements of both $\gamma$ - and $\beta$-chain genes, whereas the remaining six had no rearrangements of $\boldsymbol{\gamma}$ - and $\boldsymbol{\beta}$-chain genes. These findings indicated that $\alpha$-chain gene rearrangement is not specific for $T$ lineage cells and $\boldsymbol{\gamma}$ - and/or $\boldsymbol{\beta}$-chain gene rearrangement does not appear essential for $\alpha$-chain gene rearrangement, at least in B-precursor leukemic cells.
\end{abstract}

\section{Introduction}

On the basis of immunologic and enzymatic analyses, acute leukemias are presumed to result from clonal expansion of cells that are arrested at a specific stage of differentiation $(1,2)$. This hypothesis has been supported by studies of rearrangements of $\mathrm{Ig}$ and $\mathrm{T}$ cell receptor (TCR) ${ }^{1} \beta$ - and $\gamma$-chain genes in leukemic cells (3-10). The characterization of Ig and TCR gene configuration is therefore useful not only for the detection of clonality but also for the investigation of lymphoid cell differentiation (11).

Three $\mathrm{T}$ cell-specific gene families, $\alpha-, \beta$-, and $\gamma$-chain genes, that rearrange during somatic development have been characterized (12-16). Rearranging $\alpha$ - and $\beta$-chain genes encode the $\alpha$ - and $\beta$-polypeptides, respectively, which comprise the antigen-specific TCR together with the T3 polypeptide

Address correspondence to Dr. Erwin W. Gelfand, Department of Pediatrics, National Jewish Center for Immunology and Respiratory Medicine, 1400 Jackson St., Denver, CO 80206.

Received for publication 6 March 1987 and in revised form 15 June 1987.

1. Abbreviations used in this paper: ALL, acute lymphoblastic leukemia; C, constant; $D$, diversity; $H$, heavy; J, joining, L, light; TCR, T cell receptor; $\mathrm{V}$, variable.

J. Clin. Invest.

(c) The American Society for Clinical Investigation, Inc.

0021-9738/87/12/1770/08 \$2.00

Volume 80, December 1987, 1770-1777 chains $(17,18)$. The protein product of the $\gamma$-chain gene may also be associated with the T3 complex, but in conjunction with a putative TCR $\delta$ protein instead of the $\alpha$ - or $\beta$-polypeptides. However, the function of TCR $\gamma$ remains uncertain $(19,20)$.

Recent studies have suggested a developmental hierarchy of Ig gene activation. In B precursor cells, Ig heavy $(\mathrm{H})$-chain gene rearrangements precede Ig light $(\mathrm{L})$-chain genes. The protein products of rearranged IgH-chain genes may inhibit further rearrangements of the $\mathrm{H}$-chain gene and activate $\mathrm{k}$ chain gene rearrangements (21). These are considered to be specific markers identifying cells of $B$ lineage (22). It is possible that an analogous series of events may characterize TCR gene activation. $\gamma$-Chain gene rearrangement and expression are the first events in $\mathrm{T}$ cell ontogeny, followed by $\beta$-chain gene rearrangement and expression. $\alpha$-Chain gene expression is observed only in mature thymocytes and peripheral $\mathrm{T}$ cells which have $T 3$ antigen on the cell surface $(19,23-28)$. In view of this, it has been proposed that $\alpha$-chain gene rearrangements may be regulated by a product of the rearranged $\beta$-chain gene, and this specific event would be restricted to cells of $T$ lineage. The number of joining $(J)$ gene segments of the $\alpha$-chain has been estimated at $>55$, and these segments are spread over a region of $>50 \mathrm{~kb}$ (29). Because of this unique structure, an analysis of $\alpha$-chain gene rearrangements has been difficult using constant (C) region probes, and there have been no reports about the detailed analysis of $\alpha$-chain gene configuration in a large number of leukemic samples. Recently, genomic probes for $\mathrm{J} \alpha$ segments have been isolated and this has made it possible in part to analyze TCR $\alpha$-chain gene configuration (30). To delineate the hierarchy of TCR gene rearrangement and to determine the lineage specificity of TCR $\alpha$-chain gene rearrangement, we have examined $\alpha$-chain gene configuration using $\mathrm{J} \alpha$ genomic probes in addition to TCR $\gamma, \beta$, and Ig genes in 64 children with acute lymphoblastic leukemia (ALL).

\section{Methods}

Analysis of leukemic cell surface markers. Mononuclear cells were obtained from bone marrow by Ficoll-Hypaque gradient centrifugation at the time of diagnosis, before initiation of treatment. The samples evaluated contained $>85 \%$ malignant cells. Reactivity with a panel of monoclonal antibodies was assessed by indirect immunofluorescence using fluorescent microscopy (5). The diagnosis of T-ALL was made based on the expression of $\mathrm{T}$ cell-associated antigens such as $\mathrm{T} 3$ (CD3), T4 (CD4), T6 (CD1), T8 (CD8), T1 1 (CD2), Leu 1 (CD5), and WT1 (CD7). If leukemic cells lacked both T cell-associated antigens and surface immunoglobulin, but expressed the $B$ cell-associated antigen B4 (CD19) and/or B1 (CD20), they were classified as B-precursor ALL.

DNA preparation. High-molecular weight DNA was extracted by routine methods from the mononuclear cells. The DNA samples were 
digested with restriction endonucleases. The digested DNA was subjected to electrophoresis in $\sim 0.6-0.9 \%$ agarose gels and transferred to nylon filters by the Southern blotting technique. Filters bonded with DNA were then hybridized to probes labeled with ${ }^{32} \mathrm{P}$ by the random primer method (31) and visualized by autoradiography.

Gene probes. The human Ig gene probes were the Ig $\mu$-chain constant region probe (1.3-kb Eco RI fragment, provided by Drs. T. H. Rabbitts and G. Matthyssens) (32) and the Ig k-chain constant region probe (2.5-kb Eco RI fragment provided by Dr. P. Leder) (33). The TCR $\beta$-chain gene probe was a $0.8-\mathrm{kb}$ Bgl II-Eco RV cDNA fragment containing constant region subcloned from the cDNA clone YT-35 (12) and hybridized to both constant regions $C \beta 1$ and $C \beta 2$. Using this probe, rearrangements of either the $C \beta 1$ or $C \beta 2$ locus were detected after Bam HI digestion. Eco RI and Hind III digests demonstrated rearrangements of $C \beta 1$ and $C \beta 2$ loci, respectively (34). The TCR $\gamma$ chain gene probe was the joining region probe $(0.7-\mathrm{kb}$ Hind III-Eco RI fragment provided by Dr. T. H. Rabbitts) (35) and hybridized to $\mathrm{J} \gamma 1.3$ and $\mathrm{J} \gamma$ 2.3. After Bam HI digestion, rearrangements of $\mathrm{J} \gamma$ 1.1, $\mathrm{J} \gamma$ 1.2,

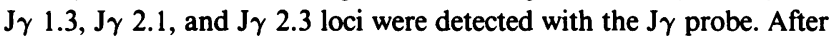
Eco RI digestion, rearrangements of only $\mathrm{J} \gamma 1.3$ and $\mathrm{J} \gamma 2.3$ loci were detected because Eco RI separated $\mathrm{J} \gamma 1.3$ and $\mathrm{J} \gamma 2.3$ from the other $\mathrm{J} \gamma$ segments (36). The TCR $\alpha$-chain gene joining region probes used in this study were the $\mathrm{J} \alpha \mathrm{B}, \mathrm{J} \alpha \mathrm{C}$, and $\mathrm{J} \alpha \mathrm{D}$ probes (2.3-, 4.7-, and 2.0-kb Eco RI fragments, respectively) (30). Of these, the $J \alpha D$ probe is the furthest upstream, about $30 \mathrm{~kb}$ from the constant region.

\section{Results}

Immunological analysis. A summary of reactivity with monoclonal antibodies for the 18 patients with T-ALL is shown in Table I. 11 of 18 patients were positive for CD3, which appears at a late stage of $\mathrm{T}$ cell development. However, the remaining seven patients did not express CD3 and were conceivably derived from an earlier stage of differentiation (37). One patient (Pt. 1) showed only reactivity with $\mathrm{CD} 7$; which recognizes the earliest $\mathrm{T}$ cell-associated antigen (38).

The B-precursor ALLs were divided into three subgroups according to the phenotypic classification proposed by Nadler et al. (39) (Table II): Ia and CD19 (Stage II, 4\%); Ia, CD19, and common ALL antigen (CALLA, CD10) (Stage III, 76\%); and Ia, CD19, CD10, and CD20 (Stage IV, 20\%). In 12 patients, BA-2 (CD9) was used instead of CD19. Leukemias belonging to Stage I (solely $\mathrm{Ia}^{+}$) were excluded from this study, as we have labeled such leukemias as unclassified. In 41 patients, cytoplasmic Ig (cIg) was examined, and 10 patients $(24 \%)$ were positive.

Ig gene rearrangement. IgH gene was analyzed by the $\mathrm{C} \mu$ probe after Bam HI digestion. Among the 18 patients with T-ALL, two patients (Pts. 2 and 8) showed a single rearranged band whose size was close to that of the germline band (Table I). As previously reported, this unique pattern was previously observed in HSB2 cells ( $T$ cell line), $T$ cell, myeloid, and unclassified leukemia (40).

39 of 46 patients with B-precursor ALL showed rearrangements of IgH-chain gene without a germline allele, and five of them had three rearranged bands indicating biclonality or chromosomal abnormality (Table II). The remaining seven patients had single allelic rearrangements with a germline configuration on the other allele. In addition, rearrangements of the $\mathrm{k}$-chain gene were examined using the $\mathrm{Ck}$ probe after Bam HI digestion in 39 patients with B-precursor ALL. 21 patients $(54 \%)$ demonstrated rearranged bands or deletion.

Table I. Surface Antigen Expression and Rearrangements of Immunoglobulin and T Cell Receptor Genes in 18 Patients with T Cell ALL

\begin{tabular}{|c|c|c|c|c|c|c|c|c|c|c|c|}
\hline \multirow[b]{3}{*}{ Pt. No. } & \multirow{2}{*}{\multicolumn{6}{|c|}{ Surface markers* }} & \multirow{3}{*}{$\frac{\text { Immunoglobulin gene }^{\ddagger}}{\mu}$} & \multicolumn{4}{|c|}{ T cell receptor genes ${ }^{\ddagger}$} \\
\hline & & & & & & & & \multirow[b]{2}{*}{$\gamma^{5}$} & \multicolumn{2}{|l|}{$\beta$} & \multirow[b]{2}{*}{$\alpha$} \\
\hline & CD7 & CD3 & CD1 & $\mathrm{CD} 2$ & CD4 & CD8 & & & Bam HI & Eco RI" & \\
\hline 1 & + & - & - & - & - & - & G & $\mathbf{R} / \mathbf{R}$ & $R / R$ & D & G \\
\hline 2 & ND & - & - & 20 & + & 30 & $R / G$ & $R / R$ & $\mathbf{R} / \mathbf{R}$ & D & G \\
\hline 3 & + & - & - & + & - & - & G & $R / R$ & $\mathrm{R} / \mathrm{D}$ & $R / D$ & G \\
\hline 4 & ND & - & - & + & + & + & G & $\mathbf{R} / \mathbf{R}$ & $\mathrm{R} / \mathrm{D}$ & R/D & G \\
\hline 5 & ND & - & + & + & + & 42 & G & $R / R$ & $\mathrm{R} / \mathrm{D}$ & D & G \\
\hline 6 & ND & - & + & + & + & + & $\mathbf{G}$ & $\mathbf{R} / \mathbf{R}$ & R/D & D & G \\
\hline 7 & ND & - & 30 & + & - & + & G & $\mathbf{R} / \mathbf{R}$ & $\mathrm{R} / \mathrm{D}$ & $\mathrm{R} / \mathrm{D}$ & G \\
\hline 8 & + & + & 20 & - & + & - & $\mathrm{R} / \mathrm{G}$ & $\mathbf{R} / \mathbf{R}$ & $\mathbf{R} / \mathbf{R}$ & R/D & $\mathrm{R} / \mathrm{G}$ \\
\hline 9 & ND & 18 & 18 & + & - & 20 & G & $R / R$ & $\mathbf{R} / \mathbf{R}$ & $\mathbf{R} / \mathbf{R}$ & $\mathbf{G}$ \\
\hline 10 & ND & + & + & + & 40 & 40 & G & $\mathbf{R}$ & $R / D$ & $R / D$ & G \\
\hline 11 & ND & + & 44 & + & 19 & - & G & $R / R$ & $R / R$ & $R / D$ & G \\
\hline 12 & ND & 15 & + & + & 10 & + & G & $\mathbf{R} / \mathbf{R}$ & R/D & $R / D$ & G \\
\hline 13 & ND & + & 30 & + & 29 & + & $\mathbf{G}$ & $R / R$ & $R / R$ & D & G \\
\hline 14 & ND & 30 & + & + & + & + & G & $\mathbf{R} / \mathbf{R}$ & $R / R$ & R/D & G \\
\hline 15 & + & + & - & + & - & - & $\mathbf{G}$ & $\mathbf{R} / \mathbf{R}$ & $R / R$ & $\mathbf{R} / \mathbf{R}$ & $\mathrm{R} / \mathrm{G}$ \\
\hline 16 & ND & + & - & - & 27 & - & $\mathbf{G}$ & $R / R$ & $R / R$ & D & G \\
\hline 17 & ND & 33 & - & + & 42 & 45 & G & $R / R$ & $R / R$ & $R / R$ & G \\
\hline 18 & ND & + & - & + & - & - & $\mathbf{G}$ & $R / R$ & $R / R$ & $R / D$ & G \\
\hline
\end{tabular}

${ }^{*}(-)<10 \%$ positive cells; $(+)>50 \%$ positive cells. Numbers are specific percentages of positive cells. ${ }^{\ddagger}(\mathrm{R})$ rearranged; (G) germline; (D) deleted. ${ }^{\S}$ Patterns after Bam HI digestion are shown. In all patients except for Pt. 6, there was no retained germline band. Pt. 6 retained one germline band corresponding to $\gamma^{2}$ locus, and an additional rearranged band that was not detected after Eco RI digestion was demonstrated after Bam HI digestion. "Patterns of bands corresponding to $C \beta 1$ locus. 
Table II. Rearrangement of Immunoglobulin and T Cell Receptor Genes in 46 Patients with B-Precursor ALL

\begin{tabular}{|c|c|c|c|c|c|c|c|c|c|}
\hline \multirow[b]{3}{*}{ Group } & \multirow[b]{3}{*}{ Pt. No. } & \multirow[b]{3}{*}{ Phenotype $^{\ddagger}$} & \multicolumn{2}{|c|}{ Immunoglobulin genes* } & \multicolumn{5}{|c|}{$\mathrm{T}$ cell receptor genes ${ }^{*}$} \\
\hline & & & \multirow[b]{2}{*}{$\mu$} & \multirow[b]{2}{*}{$\kappa$} & \multirow{2}{*}{\multicolumn{2}{|c|}{$\gamma^{8}$}} & \multicolumn{2}{|l|}{$\beta$} & \multirow[t]{2}{*}{$\alpha$} \\
\hline & & & & & & & Bam HI & Eco RI" & \\
\hline \multirow{13}{*}{ A } & 19 & II & $\mathrm{R} / \mathrm{R} / \mathrm{R}$ & $\mathrm{D}$ & \multicolumn{2}{|l|}{ G } & G & G & G \\
\hline & 20 & II & $\mathrm{R} / \mathrm{G}$ & G & \multicolumn{2}{|l|}{ G } & G & G & G \\
\hline & 21 & III & $\mathrm{R} / \mathrm{D}$ & $\mathrm{D}$ & \multicolumn{2}{|l|}{ G } & G & G & G \\
\hline & 22 & III & $\mathrm{R} / \mathrm{D}$ & $\mathrm{D}$ & \multicolumn{2}{|l|}{ G } & G & G & G \\
\hline & 23 & III & $\mathrm{R} / \mathrm{R} / \mathrm{R}$ & R/D & \multicolumn{2}{|l|}{ G } & G & G & G \\
\hline & 24 & III & $\mathrm{R} / \mathrm{D}$ & G & \multicolumn{2}{|l|}{ G } & G & G & G \\
\hline & 25 & III & $R / R$ & G & \multicolumn{2}{|l|}{ G } & G & G & G \\
\hline & 26 & III & $\mathrm{R} / \mathrm{G}$ & ND & \multicolumn{2}{|l|}{ G } & G & G & G \\
\hline & 27 & III $^{\top}$ & $\mathrm{R} / \mathrm{R} / \mathrm{R}$ & $\mathrm{R} / \mathrm{G}$ & \multicolumn{2}{|l|}{$\mathrm{G}$} & G & G & G \\
\hline & 28 & III & $\mathrm{R} / \mathrm{D}$ & $\mathrm{G}$ & G & & G & G & G \\
\hline & 29 & III & $R / R$ & ND & G & & G & G & G \\
\hline & 30 & $I^{9}$ & $R / R$ & G & G & & G & G & G \\
\hline & 31 & IV & $\mathrm{R} / \mathrm{R} / \mathrm{R}$ & R/D & G & & G & G & G \\
\hline & 32 & III & $R / R$ & R/D & $\mathbf{R}$ & $\mathrm{D}^{* *} / \mathrm{G}^{\ddagger \ddagger \S \S}$ & G & G & G \\
\hline & 33 & III & $R / R$ & $\mathrm{D}$ & $\mathbf{R}$ & $D / G^{\S \S}$ & G & G & G \\
\hline & 34 & III & $\mathrm{R} / \mathrm{R}$ & $R / R$ & $\mathbf{R}$ & $\mathrm{G} / \mathrm{G}$ & G & G & G \\
\hline B & 35 & III & $R / R$ & $\mathrm{G}$ & $\mathbf{R}$ & $\mathrm{D} / \mathrm{G}$ & G & G & G \\
\hline B & 36 & III & $R / D$ & ND & $\mathbf{R}$ & $\mathrm{G} / \mathrm{G}$ & G & G & G \\
\hline & 37 & IV & $\mathrm{R} / \mathrm{G}$ & ND & $\mathbf{R}$ & $\mathrm{G} / \mathrm{G}$ & G & G & G \\
\hline & 38 & IV & $R / R$ & $\mathrm{G}$ & $\mathbf{R}$ & $\mathrm{G} / \mathrm{G}$ & G & G & G \\
\hline & 39 & IV $^{\rrbracket}$ & $R / D$ & ND & $\mathbf{R}$ & $\mathrm{G} / \mathrm{G}$ & G & G & G \\
\hline & 40 & III & $\mathrm{R} / \mathrm{D}$ & $\mathrm{R} / \mathrm{D}$ & $\mathrm{R}$ & $\mathrm{G} / \mathrm{G}$ & $\mathrm{R} / \mathrm{G}$ & G & \\
\hline & 41 & III" $^{\pi}$ & $\mathrm{R} / \mathrm{D}$ & ND & $\mathbf{R}$ & $\mathrm{D} / \mathrm{G}$ & $R / D$ & D & G \\
\hline & 42 & III & $\mathrm{R} / \mathrm{R} / \mathrm{R}$ & $\mathrm{D}$ & $\mathrm{R}$ & $\mathrm{D} / \mathrm{G}$ & $\mathrm{R} / \mathrm{D}$ & D & G \\
\hline & 43 & III & $R / D$ & G & $\mathbf{R}$ & $\mathrm{G} / \mathrm{G}$ & $R / G$ & G & G \\
\hline $\mathrm{C}$ & 44 & III & $R / R$ & ND & $\mathbf{R}$ & $\mathrm{D} / \mathrm{G}$ & $\mathrm{R} / \mathrm{R}$ & $\mathrm{D}$ & G \\
\hline & 45 & III & $R / R$ & D & $\mathrm{R}$ & $\mathrm{G} / \mathrm{G}$ & $\mathrm{R} / \mathrm{G}$ & G & G \\
\hline & 46 & IV & $R / R$ & G & $\mathbf{R}$ & $\mathrm{G} / \mathrm{G}$ & $\mathrm{R} / \mathrm{D}$ & D & G \\
\hline & 47 & IV & $R / R$ & $\mathrm{D}$ & $\mathbf{R}$ & $\mathrm{D} / \mathrm{G}$ & $R / R$ & D & G \\
\hline & 48 & IV & $\mathrm{R} / \mathrm{G}$ & $\mathrm{R} / \mathrm{G}$ & $\mathbf{R}$ & $\mathrm{D} / \mathrm{D}$ & $\mathrm{R} / \mathrm{G}$ & G & G \\
\hline & 49 & III & $\mathrm{D} / \mathrm{D}$ & $\mathrm{D}$ & $\mathbf{R}$ & $\mathrm{D} / \mathrm{G}$ & $\mathrm{R} / \mathrm{D}$ & D & $\mathrm{R} / \mathrm{G}$ \\
\hline & 50 & III $^{\text {" }}$ & $\mathrm{R} / \mathrm{G}$ & G & $\mathrm{R} / \mathrm{R}$ & $\mathrm{D} / \mathrm{G}$ & $\mathrm{R} / \mathrm{G}$ & G & $\mathrm{R} / \mathrm{G}$ \\
\hline & 51 & III & $R / R$ & G & $\mathbf{R}$ & $\mathrm{G} / \mathrm{G}$ & $\mathrm{R} / \mathrm{R}$ & D & $\mathrm{R} / \mathrm{G}$ \\
\hline & 52 & III $^{\pi}$ & $R / D$ & $\mathrm{G}$ & $\mathbf{R}$ & $\mathrm{G} / \mathrm{G}$ & $\mathrm{R} / \mathrm{G}$ & G & $R / R$ \\
\hline $\mathrm{D}$ & 53 & III & $R / D$ & D & $\mathrm{R} / \mathrm{R}$ & $\mathrm{D} / \mathrm{G}$ & $\mathrm{R} / \mathrm{D}$ & D & $R / R$ \\
\hline & 54 & III & $R / R$ & $\mathrm{R} / \mathrm{D}$ & $\mathrm{R} / \mathrm{R}$ & $\mathrm{D} / \mathrm{G}^{\S \S}$ & $R / R$ & $R / D$ & $\mathrm{R} / \mathrm{R}$ \\
\hline & 55 & III $^{\pi}$ & $R / R$ & $\mathrm{G}$ & $\mathrm{R} / \mathrm{R}$ & $D / G^{\S \S}$ & $\mathrm{R} / \mathrm{D}$ & D & $\mathrm{R} / \mathrm{G}$ \\
\hline & 56 & III & $\mathrm{R} / \mathrm{D}$ & $\mathrm{D}$ & $\mathrm{R} / \mathrm{R}$ & $\mathrm{D} / \mathrm{G}$ & $\mathrm{R} / \mathrm{D}$ & R/D & $\mathrm{R} / \mathrm{R}$ \\
\hline & 57 & III & $\mathrm{R} / \mathrm{G}$ & G & $\mathrm{R} / \mathrm{R}$ & $\mathrm{D} / \mathrm{G}$ & $R / R$ & $\mathrm{D}$ & $\mathrm{R} / \mathrm{G}$ \\
\hline & 58 & III & $\mathrm{R} / \mathrm{R}$ & G & $\mathrm{R} / \mathrm{R}$ & $\mathrm{D} / \mathrm{D}$ & G & G & $\mathrm{R} / \mathrm{G}$ \\
\hline & 59 & III" & $\mathrm{R} / \mathrm{D}$ & G & $\mathbf{R}$ & $\mathrm{G} / \mathrm{G}$ & G & G & $\mathrm{R} / \mathrm{G}$ \\
\hline & 60 & III" & $R / R$ & G & $\mathbf{R}$ & $\mathrm{G} / \mathrm{G}$ & G & G & $\mathrm{R} / \mathrm{G}$ \\
\hline $\mathrm{E}$ & 61 & III & $R / R$ & $\mathrm{D}$ & $\mathrm{R} / \mathrm{R}$ & $\mathrm{D} / \mathrm{G}$ & G & G & $R / R$ \\
\hline & 62 & III & $\mathrm{R} / \mathrm{D}$ & G & & $\mathrm{G}$ & G & G & $R / R$ \\
\hline & 63 & III" & $\mathrm{R} / \mathrm{G}$ & D & & $G$ & $\mathrm{R} / \mathrm{D}$ & D & $R / R$ \\
\hline & 64 & IV & $R / R$ & R/D & & G & $R / G$ & G & G \\
\hline
\end{tabular}

*(R) rearranged; (G) germline; (D) deleted. ${ }^{\ddagger}$ II, Ia and CD19 were positive; III, Ia, CD19, and CD10 were positive; IV, Ia, CD19, CD10, and CD20 were positive. \$ Patterns after Bam HI digestion are shown. "Patterns of bands corresponding to C $\beta 1$ locus. "Cytoplasmic $\mu$-chain was detected in these patients. ${ }^{* *}$ Configuration of germline band corresponding to $\gamma 1$ locus. ${ }^{\ddagger}$ Configuration of germline band corresponding to $\gamma 2$ locus. Additional rearranged bands that were not detected after Eco RI digestion were demonstrated after Bam HI digestion in these patients. 
$T C R \gamma$ - and $\beta$-chain gene rearrangement. We previously reported the analysis of TCR $\gamma$ - and $\beta$-chain gene rearrangements in T-ALL and B-precursor ALL $(7,9)$. These and additional results are summarized in Table I and II. All T-ALLs and 30 out of 46 B-precursor ALLs (65\%) showed rearrangements of the TCR $\gamma$-chain gene. Most T-ALLs (17 of 18) possessed rearranged fragments on both chromosomes and retained no germline configuration. In contrast, only eight Bprecursor ALLs showed biallelic rearrangements and germline configuration was retained in the majority of patients $(28$ of 30 ).

All T-ALLs and 20 out of 46 B-precursor ALLs (43\%) also had rearrangements of the TCR- $\beta$ chain gene. The differences in the rearrangement patterns between T-ALL and B-precursor ALL were observed after Eco RI digestion. In germline DNA, Eco RI digests yielded 11- and 4-kb fragments containing $C \beta 1$ and $C \beta 2$, respectively. The 4-kb fragment does not change in size even when the $\beta 2$ locus rearranges, because Eco RI separates $C \beta 2$ from diversity (D) gene segments and $J \beta$. With the $11-\mathrm{kb}$ fragment, 12 out of 18 patients with T-ALL showed rearranged bands without germline configuration. In contrast to T-ALL, only two out of the 20 patients with B-precursor ALL which had TCR $\beta$-chain gene rearrangements demonstrated rearranged bands after Eco RI digestion. The remaining 18 patients showed germline bands or biallelic deletions of $C \beta 1$ fragments in the absence of a rearranged band.

$T C R \alpha$-chain rearrangement. A restriction enzyme map of TCR $\alpha$-chain and the genomic J $\alpha$ probes used in this study are shown in Fig. 1. If a $J \alpha$ segment in a restriction fragment recognized by one of these probes recombines with a variable $(\mathrm{V})$ or a putative $\mathrm{D}$ segment, $\mathrm{J} \alpha$ sequences located upstream of the recombination site are deleted, the size of the resulting fragment becomes different from germline, and a rearranged band is observed.

DNA samples digested with Eco RI, Hind III, and Bgl II were examined. As shown in Figs. 2 and 3, in germline DNA, Eco RI digests yielded 2.3-, 4.7-, and 8.3-kb fragments corresponding to the $\mathrm{J} \alpha \mathrm{B}, \mathrm{J} \alpha \mathrm{C}$, and $\mathrm{J} \alpha \mathrm{D}$ probes, respectively. After Hind III digestion, a 4.8-kb fragment was recognized by the $\mathrm{J} \alpha \mathrm{D}$ probe, and three fragments $(0.7,1.7$, and $5.3 \mathrm{~kb})$ were recognized by the $J \alpha C$ probe. In an attempt to detect allelic deletion clearly, Eco RI digests were hybridized with these three probes at the same time and the intensity ratio of each band was assessed by densitometry in comparison with a germline control. Furthermore, in blots digested with Hind III, the DNA hybridization ratio between the $4.8-\mathrm{kb}$ ( $\mathrm{J} \alpha \mathrm{D}$ probe) and $5.3-\mathrm{kb}(\mathrm{J} \alpha \mathrm{C}$ probe) bands was assessed in the same manner. In cases where rearranged bands were demonstrated, the rearranged band was screened by hybridization with single probes. The enzyme Bgl II produced 9.3- and 5.7-kb fragments identified by the $\mathrm{J} \alpha \mathrm{C}$ probe in germline DNA (Fig. 4). The $5.7-\mathrm{kb}$ fragment was not rearranged without a deletion of the 9.3-kb fragment. We concluded, therefore, that the 9.3-kb fragment lies upstream of the $5.7-\mathrm{kb}$ fragment and contains a large part of the regions upstream of the $\mathrm{J} \alpha \mathrm{C}$ sequences. This digestion was useful to identify rearrangements involving $\mathrm{J} \alpha$ segments located between the $\mathrm{J} \alpha \mathrm{C}$ and the $\mathrm{J} \alpha \mathrm{D}$ probes.

The patterns of $\alpha$-chain gene rearrangement are summarized in Tables I-III. Southern blots of DNAs digested with Eco RI from T-ALL patients are shown in Fig. $2 \mathrm{~A}$. No rearranged bands were observed. However, in two patients (Pts. 8 and 15 ), single allelic deletions of the $\mathrm{J} \alpha \mathrm{D}$ sequences were detected based on decreased intensity of the $8.3-\mathrm{kb}$ bands and were confirmed after Hind III digestion (Fig. $2 \mathrm{~B}$ ). In addition, Pt. 15 showed a rearranged $\mathrm{Bgl}$ II band hybridizing to the $\mathrm{J} \alpha \mathrm{C}$ probe (Fig. 4).

15 out of 46 DNA samples digested with Eco RI from B-precursor ALL patients (33\%) demonstrated rearranged bands and/or deletions (Tables II and III). Fig. 3, $A$ and $C$ shows the pattern of rearrangements in these 15 patients. In 7 of 15 , there were deletions of the $\mathrm{J} \alpha \mathrm{D}$ sequences on both alleles (Pts. 52, 53, 54, 56, 61, 62, and 63); another seven showed single allelic deletions of these regions without any rearranged band (Pts. 49, 50, 55, 57, 58, 59, and 60), and the remaining patient (Pt. 51) had a single allelic rearranged band corresponding to the $\mathrm{J} \alpha \mathrm{D}$ sequences while retaining germline configuration on the other allele. One (Pt. 63) of the first group had a single rearranged band containing the $\mathrm{J} \alpha \mathrm{C}$ sequences and deleted the germline bands corresponding to the $\mathrm{J} \alpha \mathrm{C}$ and $\mathrm{J} \alpha \mathrm{D}$ probes. Single allelic deletion corresponding to the $\mathrm{J} \alpha \mathrm{B}$ probe was suggested in this patient by the DNA hybridization ratio. This suggested that a $\mathrm{J} \alpha$ segment in the $\mathrm{J} \alpha \mathrm{C}$ sequences was involved in the rearrangement, and $\mathrm{J} \alpha$ regions located upstream of at least the $3^{\prime}$ terminus of the $\mathrm{J} \alpha \mathrm{B}$ sequences were deleted on the other allele. Also in the first group, Pt. 53 showed deletions of $\mathrm{J} \alpha$ segments corresponding to the $\mathrm{J} \alpha \mathrm{D}$ sequences on one allele and to the $\mathrm{J} \alpha \mathrm{B}, \mathrm{J} \alpha \mathrm{C}$, and $\mathrm{J} \alpha \mathrm{D}$ sequences on the other allele. These findings after Eco RI digestion were confirmed by Hind III digestion (Fig. 3, $B$ and $D$ ). In 12 of 15 patients, DNA samples digested with $\mathrm{Bgl}$ II were hybridized with the $\mathrm{J} \alpha \mathrm{C}$ probe (Fig. 4). Rearranged bands were demonstrated in five patients (Pts. 54, 55, 56, 61, and 63). Except for Pt. 63, these patients retained germline configuration. The two apparently rearranged bands in Pt. 54 could represent one somatic rearrangement plus a chromosomal abnormality.

Overall, in 13 of 15 patients with B-precursor ALL having rearrangements of $\alpha$-chain gene, $\mathrm{J} \alpha$ segments located between the $\mathrm{J} \alpha \mathrm{C}$ and the $\mathrm{J} \alpha \mathrm{D}$ sequences were involved in these rearrangements. Moreover, based on the experiments using Bgl II digestion, in the majority of these patients, the rearrangements occurred between the $3^{\prime}$ site of $\mathrm{J} \alpha \mathrm{D}$ sequences and the Bgl II restriction site located upstream of the $\mathrm{J} \alpha \mathrm{C}$ sequences ( $\mathrm{Ta}$ ble III).

Patients with unusual combinations of TCR gene rearrangements. After analysis of the findings of TCR gene configuration, the 46 patients with B-precursor ALL were tentatively divided into five subgroups as shown in Table II. Most patients

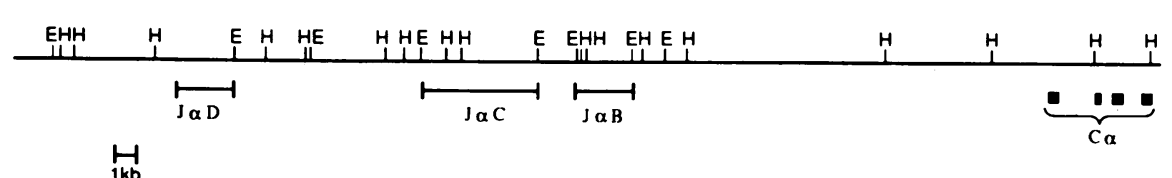

$\underset{1 \mathrm{~kb}}{H}$
Figure 1. A restriction map of TCR $\alpha$ chain gene and the genomic $\mathrm{J} \alpha$ probes used in this study. $(E)$ Eco RI; $(H)$ Hind III restriction sites. $\mathrm{Bgl}$ II restriction sites are uncertain. 


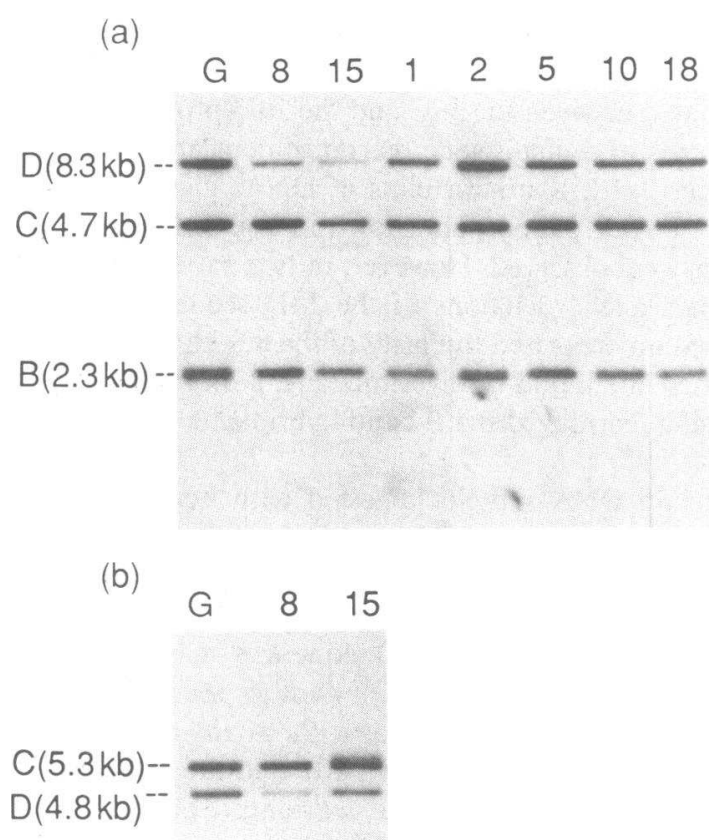

Figure 2. The rearrangement patterns of TCR $\alpha$-chain gene in patients with $\mathrm{T}$ cell acute lymphoblastic leukemia. Patient numbers are noted above each lane. Lane $G$ shows the germline control. Dotted lines $B, C$, and $D$ on either side of each gel indicate the germline positions corresponding to the $\mathrm{J} \alpha \mathrm{B}, \mathrm{J} \alpha \mathrm{C}$ and $\mathrm{J} \alpha \mathrm{D}$ probes, respectively. (a) DNAs were digested with Eco RI and were hybridized with the $\mathrm{J} \alpha \mathrm{B}, \mathrm{J} \alpha \mathrm{C}$, and $\mathrm{J} \alpha \mathrm{D}$ probes at the same time. The $\mathrm{J} \alpha \mathrm{B}, \mathrm{J} \alpha \mathrm{C}$, and $\mathrm{J} \alpha \mathrm{D}$ probes demonstrated 2.3-, 4.7-, and 8.3-kb bands, respectively, in germline DNA. A faint band just below the $\mathrm{J} \alpha \mathrm{C}$ band in Pt. 15 was due to cross-hybridization. Similar bands were observed in the other lanes on the original film. (b) DNAs were digested with Hind III and were hybridized with the $\mathrm{J} \alpha \mathrm{C}$ and the $\mathrm{J} \alpha \mathrm{D}$ probes at the same time. The $\mathrm{J} \alpha \mathrm{C}$ and the $\mathrm{J} \alpha \mathrm{D}$ probes demonstrated three bands (0.7-, 1.7-, and 5.3-kb) and 4.8-kb band, respectively, in germline DNA. 0.7and $1.7-\mathrm{kb}$ bands corresponding to the $\mathrm{J} \alpha \mathrm{C}$ probe are not shown in this figure.

with B-precursor ALL showed a combination of TCR gene rearrangements consistent with the proposed hierarchy that $\gamma$-chain gene rearrangement is the first event followed by $\beta$ chain rearrangement and subsequently $\alpha$-chain gene rearrangement $(19,23-28)$. However, seven patients (Group E) demonstrated unusual combinations of TCR gene rearrangements. Patients 58 through 61 had rearrangements of the $\alpha$ chain gene despite retention of germline configuration of the $\beta$-chain gene; three patients (Pts. 62-64) had rearrangements of the $\beta$ - and/or $\alpha$-chain gene while retaining germline configuration of $\gamma$-chain gene.

\section{Discussion}

Lymphoid leukemias are presumed to result from the clonal expansion of cells arrested at different stages of lymphoid ontogeny $(1,2)$. These leukemias offer the opportunity to analyze clonal cells, and molecular analysis of these cells is a powerful tool for investigation of the differentiation of lymphoid precursor cells. Analyses of Ig, TCR $\beta$-, and $\gamma$-chain gene rearrangements have been reported for leukemic patients, and these data have provided insights into the differentiation process of hematopoietic cells (3-11, 40-42).

In the present study, we have analyzed $\alpha$-chain gene configuration in addition to the TCR $\gamma, \beta$, and Ig genes in 64 children with ALL using three genomic $\mathbf{J} \alpha$ probes. Rearrangements of the $\alpha$-chain gene were observed not only in T-ALL but also B-precursor ALL. In this way, we have demonstrated further heterogeneity of B-precursor ALL at the gene level. These data also indicated that similar to $\gamma$ - and $\beta$-chain genes, rearrangement of the $\alpha$-chain gene is not specific for T-lineage cells and cannot therefore be used as a specific marker indicating $\mathrm{T}$ cell lineage.

All 18 T-ALL patients had rearrangements of both $\gamma$ - and $\beta$-chain genes, but rearrangements of $\alpha$-chain genes were observed in only 2 of 18 patients with T-ALL (Table I). Leukemic cells from these two patients expressed T3 antigen on the cell surface. Although it has been reported that a population of $\mathrm{T}$ cells expresses T3 antigen in the absence of the $\alpha / \beta$ heterodimer, such a population was infrequent $(19,20,43)$. Furley et al. reported that all T-ALL patients whose leukemic cells had T3 antigen on the cell surface expressed $1.6 \mathrm{~kb}$ messenger RNA of the $\alpha$-chain gene which is conceivably functional, and suggested rearrangement of the $\alpha$-chain gene in these patients (28). In the present study, 11 out of $18 \mathrm{~T}$-ALLs expressed T3 antigen. If one assumes that these 11 patients have rearrangements of the $\alpha$-chain gene, $\mathrm{J} \alpha$ segments located in the region recognized by the $\mathrm{J} \alpha \mathrm{B}, \mathrm{J} \alpha \mathrm{C}$, and $\mathrm{J} \alpha \mathrm{D}$ probes were involved in only two of the 11 patients, and leukemic cells from the remaining nine patients should therefore have rearrangements involving $\mathrm{J} \alpha$ segments located upstream of the $\mathrm{J} \alpha \mathrm{D}$ sequences. Although we cannot completely rule out the possibility of single allelic deletion of the whole $\mathrm{J} \alpha \mathrm{B}$ sequences and $\mathrm{J} \alpha$ regions located upstream of them, considering the amount of DNA, it seemed unlikely. On the contrary, $\alpha$-chain gene rearrangements were observed in $75 \%$ of cloned functional $\mathrm{T}$ cell lines with the probes used in this study and similar digestions (30). Rearrangements of $\mathrm{J} \alpha$ regions located upstream of the $\mathrm{J} \alpha \mathrm{D}$ sequences may be favored in T-ALL.

Rearrangements of the $\alpha$-chain gene were also demonstrated in 15 of $46(33 \%)$ B-precursor ALL patients (Table II). Surprisingly, in contrast to the findings in T-ALL, rearrangements in 13 of these 15 patients involved $\mathrm{J} \alpha$ segments located between the $3^{\prime}$ site of the $\mathrm{J} \alpha \mathrm{D}$ probe and the $5^{\prime}$ site of the $\mathrm{J} \alpha \mathrm{C}$ probe (Table III). It is not clear why $\alpha$-chain gene rearrangement in B-precursor leukemic cells should favor a recombination site that was rarely observed in $\mathrm{T}$ leukemic cells.

Patients (Pts. 58-64) with unusual combinations of TCR gene rearrangements were also observed. Four patients (Pts. 58-61) had rearrangements of both $\gamma$ - and $\alpha$-chain genes despite germline configuration of the $\beta$-chain gene; Pts. 62 and 64 had $\alpha$ - or $\beta$-chain gene rearrangements alone, respectively. Pt. 63 had rearrangements of both $\beta$ - and $\alpha$-chain genes without $\gamma$-chain gene rearrangement. These findings suggest that the order of TCR gene rearrangement may not always be strict and that products of rearranged $\gamma$ - or $\beta$-chain genes may not be essential for the next step of gene rearrangement, i.e., $\beta$ - or $\alpha$-chain gene rearrangement, at least in B-precursor cells. The TCR gene system therefore seems to be different from the IgH-chain and L-chain genes where IgL-chain gene rearrangements have never been observed without IgH-chain gene rearrangements and the protein products of rearranged IgH-chain genes may be necessary for IgL-chain gene rearrangement (21). 
(a)
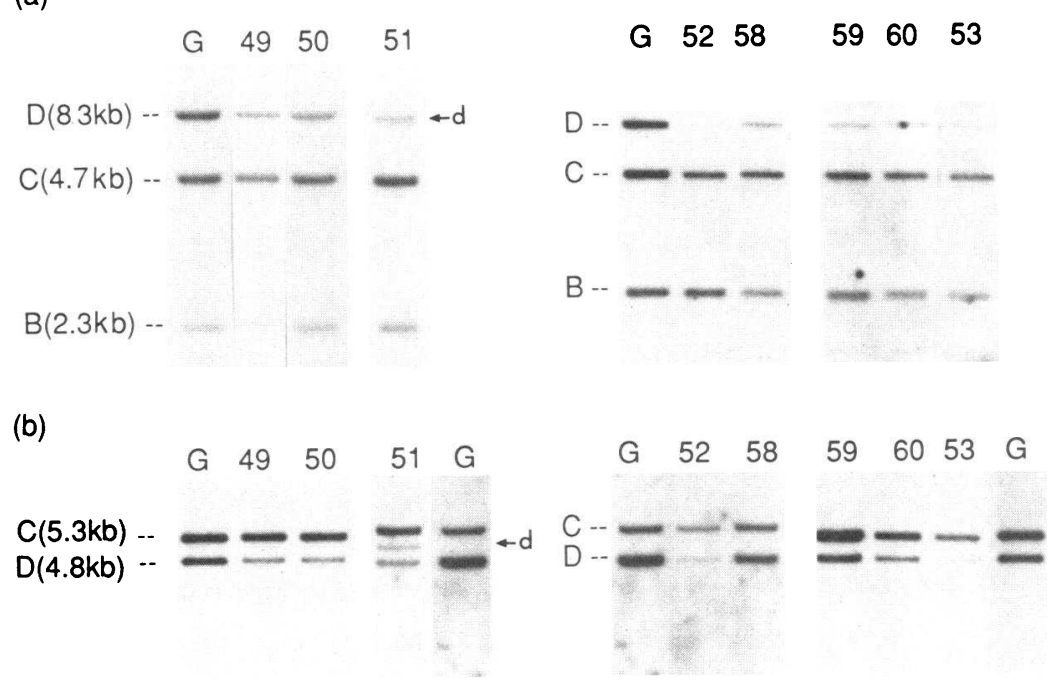

(c)
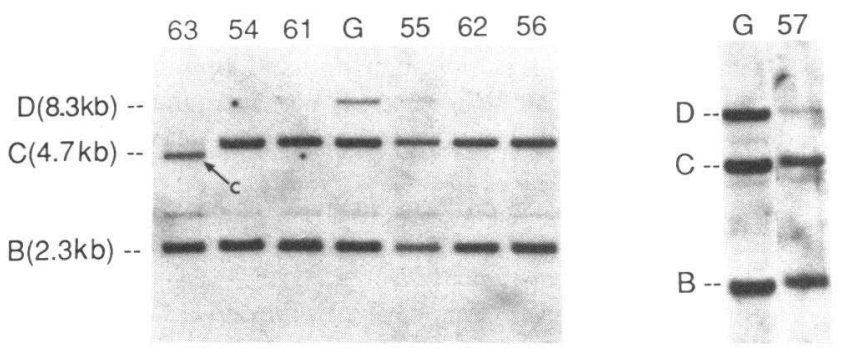

(d)

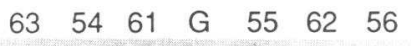

$\mathrm{C}(5.3 \mathrm{~kb})$

$\mathrm{D}(4.8 \mathrm{~kb})$
Figures 3. Rearrangement patterns of TCR $\alpha$-chain gene in patients with B-precursor acute lymphoblastic leukemia. Patient numbers are noted above each lane. Lane $G$ shows the germline control. Dotted lines $B, C$, and $D$ on either side of each gel indicate the germline positions corresponding to the $\mathrm{J} \alpha \mathrm{B}, \mathrm{J} \alpha \mathrm{C}$, and $\mathrm{J} \alpha \mathrm{D}$ probes, respectively. Rearranged bands are indicated by arrows $(c)$ and $(d)$ corresponding to the $\mathrm{J} \alpha \mathrm{C}$ and the $\mathrm{J} \alpha \mathrm{D}$ probes, respectively, on the gels. $(a)$ and $(c)$ DNAs were digested with Eco RI and were hybridized with the $\mathrm{J} \alpha \mathrm{B}$, $\mathrm{J} \alpha \mathrm{C}$, and $\mathrm{J} \alpha \mathrm{D}$ probes at the same time. $(b)$ and $(d)$ DNAs were digested with Hind III and were hybridized with the $\mathrm{J} \alpha \mathrm{C}$ and the $\mathrm{J} \alpha \mathrm{D}$ probes at the same time. Faint $\mathrm{J} \alpha \mathrm{D}$ bands in Pts. 52, $53(a)$, and $61(c)$ represent DNA from contaminating nonleukemic cells. Weak hybridizations caused by cross-hybridization were observed just above $\mathrm{J} \alpha \mathrm{B}$ or below $\mathrm{J} \alpha \mathrm{C}$ bands in $c$.

in liver and a population of early thymocytes had no rearrangement of the $\beta$-chain gene, and suggested that $\beta$ - and $\alpha$ chain gene rearrangements occur in the thymus (27). Moreover, leukemic cells having no CD3 or CD1, but expressing CD7 which is the earliest T cell-associated antigen, frequently had no rearrangement of the $\beta$-chain gene $(10,44)$. Therefore, $\beta$ - and $\alpha$-chain gene rearrangements may be events occurring after the commitment to $\mathrm{T}$ cell lineage, and such phenomena may not be observed in uncommitted cells. Accordingly, if leukemic cells from B-precursor ALL are presumed to be the counterparts of normally developing cells, then it is possible that $\beta$ - or $\alpha$-chain gene rearrangements in such cells may also occur after the commitment to B cell lineage concomitantly with rearrangements of IgH- and L-chain genes by an activated common recombinational system (45). Rearrangements of $\beta$ and $\alpha$-chain genes in these cells may then be independent of the thymus. Such extrathymic rearrangement of TCR genes has been observed in nude mice (46). Subsequently and irrespective of the configuration of TCR genes, only precursor B cells that accomplished productive rearrangements of both IgH- and L-chain genes would differentiate to functional B cells. Other cells would be eliminated.

In this study, a significant proportion of patients with B- 
Table III. Patterns of T Cell Receptor $\alpha$-Chain

Gene Rearrangements

\begin{tabular}{|c|c|c|c|c|c|}
\hline & \multirow[b]{2}{*}{ Pt. No. } & \multirow{2}{*}{$\frac{\mathrm{J} \alpha \mathrm{B}}{\mathrm{Eco} \mathrm{RI}}$} & \multicolumn{2}{|l|}{$\mathrm{J} \alpha \mathrm{C}$} & \multirow{2}{*}{$\begin{array}{l}\mathrm{J} \alpha \mathrm{D} \\
\text { Eco RI, } \\
\text { Hind III }\end{array}$} \\
\hline & & & $\begin{array}{l}\text { Eco RI, } \\
\text { Hind III }\end{array}$ & Bgl II & \\
\hline \multirow[t]{2}{*}{ T-ALL } & 8 & G & G & G & $D / G$ \\
\hline & 15 & G & G & $\mathrm{R} / \mathrm{G}$ & $\mathrm{D} / \mathrm{G}$ \\
\hline \multirow[t]{15}{*}{ B-precursor ALL } & 49 & G & G & ND & $D / G$ \\
\hline & 50 & G & G & $\mathrm{G}$ & $D / G$ \\
\hline & 51 & G & G & ND & $\mathrm{R} / \mathrm{G}$ \\
\hline & 52 & G & G & G & D \\
\hline & 53 & $D / G$ & $\mathrm{D} / \mathrm{G}$ & $D / G$ & D \\
\hline & 54 & G & $\mathrm{G}$ & $\mathrm{R} / \mathrm{R} / \mathrm{G}$ & D \\
\hline & 55 & G & G & $\mathrm{R} / \mathrm{G}$ & $D / G$ \\
\hline & 56 & G & $\mathrm{G}$ & $\mathrm{R} / \mathrm{G}$ & D \\
\hline & $57^{*}$ & G & G & ND & $D / G$ \\
\hline & 58 & G & G & $\mathrm{G}$ & $D / G$ \\
\hline & 59 & $\mathbf{G}$ & G & G & $D / G$ \\
\hline & 60 & G & G & G & $\mathrm{D} / \mathrm{G}$ \\
\hline & 61 & G & G & $R / G$ & D \\
\hline & 62 & G & G & G & D \\
\hline & 63 & $\mathrm{D} / \mathrm{G}$ & $\mathrm{R} / \mathrm{D}$ & $\mathrm{R} / \mathrm{D}$ & D \\
\hline
\end{tabular}

$(R)$ rearranged; $(G)$ germline; (D) deleted.

* Hind III digestion was not done in this patient.

precursor ALL showed rearrangements of TCR genes (Table II). However, the pattern of rearrangements was readily distinguished from those observed in T-ALL. The majority of patients with B-precursor ALL (93\%) retained germline fragments of the $\gamma$-chain gene, but no patients with T-ALL other than the exceptional patient had any germline configuration of the $\gamma$-chain gene. In most B-precursor ALL, C $\beta 1$ fragments were completely deleted or retained without any rearranged bands, and only $10 \%$ showed rearrangements to $C \beta 1$. In contrast, $67 \%$ of T-ALL showed rearrangement to $C \beta 1$. Furthermore, B-precursor ALL, which did rearrange the $\alpha$-chain gene, exhibited a preferred site of recombination that was seen rarely in T-ALL. Conversely, single allelic IgH-chain gene rearrangements were observed in two patients with T-ALL. However, rearrangements in these two patients showed the unique pattern of a close doublet which we have previously reported (40) and which was never observed in B-precursor ALL. Most Bprecursor ALL (85\%) retained no germline of the IgH-chain gene.

In summary, the findings in the present study indicate that TCR $\alpha$-chain gene rearrangements frequently occur in B-precursor leukemic cells and are not specific for $T$ lineage cells. In addition, in B-precursor leukemic cells, products of rearranged $\gamma$ - or $\beta$-chain genes are not always required for $\alpha$-chain gene rearrangement. Rearrangements of the $\alpha$-, $\beta$-, and $\gamma$-chain genes are prevalent in B-precursor ALL. Nonetheless, the patterns of TCR gene rearrangements are in general distinguishable in B-precursor ALL from T-ALL. Coupled with Ig gene studies, it is possible to assign cell lineage to the majority of childhood ALL.

\section{Acknowledgments}

We are indebted to the members of the Division of Hematology/Oncology for providing patient specimens, to A. Goldstein for surface marker studies, and Dr. P. Doherty and Dr. G. Mills for helpful discussions. Drs. T. H. Rabbitts, G. Matthyssens, and P. Leder kindly provided the $\mathrm{T} \gamma$ and $\mathrm{Ig}$ probes.

Supported by the National Cancer Institute of Canada, the Medical Research Council of Canada and the Muscular Dystrophy Foundation. Dr. Hara and Dr. Benedict are recipients of Terry Fox Fellowship awards.

\section{References}

1. Greaves, M. F., G. Janossy, J. Peto, and H. Kay. 1981. Immunologically defined subclasses of acute lymphoblastic leukemia in children: their relationship to presentation features and prognosis. $\mathrm{Br}$. $J$. Haematol. 48:179-197.

2. Greaves, M. F., and G. Janossy. 1978. Patterns of gene expression and the cellular origins of human leukemias. Biochim. Biophys. Acta. 516:193-230.

3. Korsmeyer, S. J., P. A. Hieter, J. V. Ravetch, D. G. Poplack, T. A. Waldmann, and P. Leder. 1981. Developmental hierarchy of immunoglobulin gene rearrangements in human leukemic pre-B-cells. Proc. Natl. Acad. Sci. USA. 78:7096-7100.

4. Korsmeyer, S. J., A. Arnold, A. Bakhshi, J. V. Ravetch, U. Siebenlist, P. A. Hieter, S. O. Sharrow, T. W. Lebin, J. H. Kersey, D. G. Poplack, P. Leder, and T. A. Waldmann. 1983. Immunoglobulin gene rearrangement and cell surface antigen expression in acute lymphocytic leukemias of $\mathrm{T}$ cell and B cell precursor origins. J. Clin. Invest. 71:301-313.

5. Ha, K., N. Hozumi, and E. W. Gelfand. 1985. Lineage specific classification of leukemia: results of the analysis of sixty cases of childhood leukemia. Br. J. Haematol. 61:237-249.

6. Minden, M. D., B. Toyonaga, K. Ha, Y. Yanagi, B. Chin, E. W. Gelfand, and T. W. Mak. 1985. Somatic rearrangement of T-cell antigen receptor gene in human T-cell malignancy. Proc. Natl. Acad. Sci. USA. 82:1224-1227.

7. Tawa, A., N. Hozumi, M. Minden, T. W. Mak, and E. W. Gelfand. 1985. Rearrangement of the T-cell receptor $\beta$-chain gene in non-T-cell non-B-cell acute lymphoblastic leukemia of childhood. $N$. Engl. J. Med. 313:1033-1037.

8. Waldmann, T. A., M. M. Davis, K. F. Bongiovanni, and S. J. Korsmeyer. 1985. Rearrangements of genes for the antigen receptor on $\mathrm{T}$ cell as markers of lineage and clonality in human lymphoid neoplasms. N. Engl. J. Med. 313:776-783.

9. Tawa, A., S. H. Benedict, J. Hara, N. Hozumi, and E. W. Gelfand. 1987. Rearrangement of the T-cell receptor $\gamma$-chain gene in childhood acute lymphoblastic leukemia. Blood. In press.

10. Davey, M. P., K. Bongiovanni, W. Kaulfersch, T. Quertermous, J. G. Seidman, M. S. Hershfield, J. Kurtzberg, B. F. Haynes, M. M. Davis, and T. A. Waldmann. 1986. Immunoglobulin and T-cell receptor gene rearrangement and expression in human lymphoid leukemia cells at different stages of maturation. Proc. Natl. Acad. Sci. USA. 83:8759-8763.

11. Hara, J., K. Kawa-Ha, K. Yumura, S. Ishihara, S. Doi, H. Yabuuchi, S. Konishi, and A. Nishikawa. 1987. Heterogeneity of acute undifferentiated leukemia at the immunoglobulin and T-cell receptor genes level. Jpn. J. Cancer Res (Gann). 78:170-175.

12. Yanagi, Y., Y. Yoshikai, K. Leggett, S. P. Clark, I. Aleksander, and T. W. Mak. 1984. A human T cell-specific cDNA clone encodes a protein having extensive homology to immunoglobulin chains. Nature (Lond.). 308:145-149.

13. Saito, H., D. M. Kranz, Y. Takagaki, A. C. Hayday, H. N. Eisen, and S. Tonegawa. 1984. A third rearranged and expressed gene in a clone of cytotoxic T lymphocytes. Nature (Lond.). 312:36-40.

14. Saito, H., D. M. Kranz, Y. Takagaki, A. C. Hayday, H. N. Eisen, and S. Tonegawa. 1984. Complete primary structure of a heterodimeric T-cell receptor deduced from cDNA sequences. Nature (Lond.). 309:757-762.

15. Quertermous, T., C. Murre, D. Dialynas, A. D. Duby, J. L. Strominger, T. A. Waldmann, and J. G. Seidman. 1986. Human T-cell 
$\gamma$ chain genes: organization, diversity and rearrangement. Science (Wash. DC). 231:252-255.

16. LeFranc, M. P., A. Forster, and T. H. Rabbitts. 1986. Rearrangement of two distinct $\mathrm{T}$-cell $\gamma$-chain variable-region genes in human DNA. Nature (Lond.). 319:420-422.

17. Acuto, O. M., M. Fabbi, A. Bensussan, C. Milanese, T. J. Campen, H. D. Royer, and E. L. Reinherz. 1985. The human T-cell receptor. J. Clin. Immunol. 5:141-157.

18. Brenner, M. B., I. S. Trowbridge, and J. L. Strominger. 1985. Crosslinking of human $\mathrm{T}$ cell receptor proteins: association between the $T$ cell idiotype subunit and the $\mathrm{T} 3$ glycoprotein heavy subunit. Cell. 40:183-190.

19. Brenner, M. B., J. McLean, D. P. Dialynas, J. L. Strominger, J. A. Smith, F. L. Owen, J. G. Seidman, S. Ip, F. Rosen, and M. S. Krangel. 1986. Identification of a putative second T-cell receptor. $\mathrm{Na}$ ture (Lond.). 322:145-149.

20. Bank, I., R. A. De Pinho, M. B. Brenner, J. Cassimeris, F. W. Alt, and L. Chess. 1986. A functional T3 molcule associated with a novel heterodimer on the surface of immature human thymocytes. Nature (Lond.). 322:179-181.

21. Alt, F. W. 1984. Exclusive immunoglobulin genes. Nature (Lond.). 312:502-503.

22. Pelicci, P. G., D. M. Knowles, and R. Dalla-Favera. 1985. Lymphoid tumors displaying rearrangements of both immunoglobulin and T-cell receptor genes. J. Exp. Med. 162:1015-1024.

23. Royer, H. D., O. Acuto, M. Fabbi, R. Tizard, K. Ramachandran, J. E. Smart, and E. L. Reinhertz. 1984. Genes encoding the Ti $\beta$ subunit of the antigen/MHC receptor undergo rearrangement during intrathymic ontogeny prior to surface $\mathrm{T} 3$ and $\mathrm{Ti}$ expression. Cell. 39:261-266.

24. Raulet, D. H., R. D. Garman, H. Saito, and S. Tonegawa. 1985. Developmental regulation of T-cell receptor gene expression. Nature (Lond.). 314:103-107.

25. Snodgrass, H. R., P. Kisielow, M. Kiefer, M. Steinmetz, and H. von Boehmer. 1985. Ontogeny of the T-cell antigen receptor within the thymus. Nature (Lond.). 313:592-595.

26. Snodgrass, H. R., Z. Dembic, M. Steinmetz, and H. von Boehmer. 1985. Expression of T-cell antigen receptor genes during fetal development in the thymus. Nature (Lond.). 315:232-233.

27. Haars, R., M. Kronenberg, W. N. Gallatin, I. L. Weissman, F. L. Owen, and L. Hood. 1986. Rearrangement and expression of T-cell antigen receptor and $\gamma$ genes during thymic development. $J$. Exp. Med. 164:1-24.

28. Furley, A. J., S. Mizutani, K. Weilbaecher, H. S. Dhaliwal, A. M. Ford, L. C. Chan, H. V. Molgaard, B. Toyonaga, T. Mak, P. van den Elsen, D. Gold, C. Terhorst, and M. F. Greaves. 1986. Developmentally regulated rearrangement and expression of genes encoding the T cell receptor-T3 complex. Cell. 46:75-87.

29. Yoshikai, Y., S. P. Clark, S. Taylor, U. Sohn, B. Wilson, M. Minden, and T. W. Mak. 1985. Organization and sequences of the variable, joining and constant region genes of the human T-cell receptor $\alpha$ chain. Nature (Lond.). 31:837-840.

30. Sangster, R. N., J. Minowada, N. Suciu-Foca, M. Minden, and T. W. Mak. 1986. Rearrangement and expression of the $\alpha, \beta$, and $\gamma$ chain $T$ cell receptor genes in human thymic leukemia cells and functional T cells. J. Exp. Med. 163:1491-1508.
31. Feinberg, A. P., and B. Vogelstein. 1983. A technique for radiolabeling DNA restriction endonuclease fragments to high specific activity. Anal. Biochem. 132:6-13.

32. Rabbitts, T. H., A. Foster, and C. P. Milstein. 1981. Human immunoglobulin heavy chain genes: evolutionary comparisons of $\mathrm{C} \mu$, $\mathrm{C} \delta$ and $\mathrm{C} \gamma$ genes and associated switch sequences. Nucleic Acids Res. 9:4509-4524.

33. Hieter, P. A., E. E. Max, J. G. Seidman, J. F. Maizel, and P. Leder. 1980. Cloned human and mouse kappa immunoglobulin constant and $\mathrm{J}$ region genes conserve homology in functional segments. Cell. 22:197-207.

34. Minden, M. D., and T. W. Mak. 1986. The structure of the T cell antigen receptor genes in normal malignant $\mathrm{T}$ cells. Blood. 68:327-336.

35. LeFranc, M. P., and T. H. Rabbitts. 1985. Two tandemly organized human genes encoding the T-cell $\gamma$ constant-region sequences show multiple rearrangement in different T-cell types. Nature (Lond.). 316:464-466.

36. Quertermous, T., W. M. Strauss, J. J. M. van Dongen, and J. G. Seidman. 1987. Human $T$ cell $\gamma$ chain joining regions and $T$ cell development. J. Immunol. 138:2687-2690.

37. Reinherz, E. L., P. C. Kung, G. Goldstein, R. H. Levey, and S. F. Schlossman. 1980. Discrete stages of human intrathymic differentiation: analysis of normal thymocytes and leukemic lymphoblasts of T-cell lineage. Proc. Natl. Acad. Sci. USA. 77:1588-1592.

38. Foon, K. A., and R. F. Todd. 1986. Immunologic classification of leukemia and lymphoma. Blood. 68:1-13.

39. Nadler, L. M., S. J. Korsmeyer, K. C. Anderson, A. W. Boyd, B. Slaughenhoupt, E. Park, J. Jensen, F. Coral, R. J. Mayer, S. E. Sallan, J. Ritz, and S. F. Schlossman. 1984. B cell origin of non-T cell acute lymphoblastic leukemia: a model for discrete stages of neoplastic and normal pre-B cell differentiation. J. Clin. Invest. 74:332-340.

40. Ha, K., M. Minden, N. Hozumi, and E. W. Gelfand. 1986. Single allelic $\mathrm{C} \mu$ gene rearrangements in patients with $\mathrm{T}$ cell and undifferentiated leukemia. Leuk. Res. 10:1-8.

41. Ha, K., M. Minden, N. Hozumi, and E. W. Gelfand. 1984. Immunoglobulin $\mu$-chain gene rearrangement in a patient with T-cell acute lymphoblastic leukemia. J. Clin. Invest. 73:1232-1236.

42. Ha, K., M. Minden, N. Hozumi, and E. W. Gelfand. 1984. Immunoglobulin gene rearrangement in acute myelogeneous leukemia. Cancer Res. 44:4658-4660.

43. Lanier, L. L., and A. Weiss. 1986. Presence of Ti (WT31) negative $\mathrm{T}$ lymphocytes in normal blood and thymus. Nature (Lond.). 324:268-270.

44. Pittaluga, S., M. Raffeld, E. H. Lipford, and J. Cossman. 1986. $3 \mathrm{~A} 1$ (CD7) expression precedes $\mathrm{T} \beta$ gene rearrangements in precursor $\mathrm{T}$ (lymphoblastic) neoplasms. Blood. 68:134-139.

45. Yancopoulos, G. D., T. K. Blackwell, H. Suh, L. Hood, and F. W. Alt. 1986. Introduced T cell receptor variable region segments recombine in pre- $B$ cells: evidence that $B$ and $T$ cells use a common recombinase. Cell. 44:251-259.

46. Ikuta, K., M. Hattori, K. Wake, S. Kano, T. Honjo, J. Yodoi, and N. Minato. 1986. Expression and rearrangement of the $\alpha, \beta$ and $\gamma$ chain genes of the $\mathrm{T}$ cell receptor in cloned murine large granular lymphocyte lines: no correlation with the cytotoxic spectrum. J. Exp. Med. 164:428-442. 